\title{
Flexible Disposal Strategy: monitoring as a key to understanding and steering environmental responses to dredging and disposal in the Scheldt Estuary.
}

Davy Depreiter, Belgium

International Marine \& Dredging Consultants

Marc Sas, Belgium

International Marine \& Dredging Consultants

Kirsten Beirinckx, Belgium

Flemish Government, Department of Maritime Access

Gert-Jan Liek, The Netherlands

Ministry of Infrastructure and the Environment, Rijkswaterstaat Zeeland

Topic: K. Hydrography in the Benelux

\section{INTRODUCTION}

The Scheldt Estuary is an intensely shipped area, holding the fairway to the ports of Flushing, Terneuzen (the Netherlands), Gent and Antwerp (Belgium). The Port of Antwerp is one of the 20 largest ports worldwide although it is located $80 \mathrm{~km}$ inland from the estuary's mouth. The shipping lanes are continuously dredged to maintain an appropriate navigable depth.

In 2005, the third deepening of the Scheldt river was decided in the treaty between the Flemish Government and the Kingdom of the Netherlands concerning the execution of the Development Plan 2010 for the Scheldt Estuary (Ontwikkelingsschets 2010 Schelde-estuarium, OS2010). The Development Plan 2010 describes projects and measures needed to evolve from the current state of the Scheldt to a desired state as defined in the Long Term Vision Scheldt Estuary (LTV) in 2030, and directives for the monitoring.

In the treaty it is stated that seagoing ships up to a draught of $13.1 \mathrm{~m}$ should - tide-independently be able to navigate to and from the port of Antwerp. Among other measures, the fairway had to be (further) deepened to fulfil this purpose. In 1970, the first deepening took place: shallow parts were dredged 3 to 4 meters deeper than before. In 1995, a second deepening was carried out, allowing a ship draught of $11.6 \mathrm{~m}$ for tide-independent navigation.

The dredging works related to the third deepening of the Scheldt estuary on Dutch territory, known as the Western Scheldt, were executed in 2010. In total, 7.7 million $\mathrm{m}^{3}$ of sediments were dredged. Since then, the shoals and sills along the main shipping channel are kept to a depth of $14.5 \mathrm{~m}$ below LAT (Lowest Astronomical Tide) through maintenance dredging. It is expected that the maintenance will initially involve 11.7 million $\mathrm{m}^{3}$ of sediments and that after a couple of years, it will have decreased to about $8 \mathrm{Mm3}$ (Consortium Arcadis-Technum, 2007).

\section{THE FLEXIBLE DISPOSAL STRATEGY}

The aforementioned treaty includes a clause in which it is stated that a flexible disposal strategy has to be carried out, in order to preserve the physical system characteristics within its natural dynamics. This strategy has to include the close monitoring of the morphological evolution of the system to allow for adaptation of the disposal strategy. This is also reflected in the Dutch and Flemish (environmental) permits for the execution of the deepening and maintenance dredging. 
The monitoring programme provided is the MONEOS-T Execution Plan 2008-2018 (Schrijver \& Plancke, 2008), expanded with bird- and seal-counts for the Western Scheldt. The MONEOS-T Execution Plan describes the measurements between 2008 and 2018 that are required to evaluate the effects related to accessibility.

The environmental impact assessment (EIA) (Consortium Arcadis-Technum, 2007) of the deepening project focusses on the investigation of the different disposal strategies. In the EIA, it was concluded that the approach of a flexible disposal strategy with disposal on the edges of specific intertidal flats, is the most environmentally friendly approach. A further consequence of disposal on the edges of the flats is that less sediments have to be disposed in the main channel, which must lead to less maintenance dredging activities. The EIA also set the condition that the intertidal flats, and their edges are to be monitored closely.

The evaluation of the estuarine system is based on a number of parameters, defined in the "Protocol conditions for flexible disposal - Quality parameters", an annex to the permit for the disposal of dredged sediments. The testing of these parameters against pre-defined criteria are the base for adapting the disposal strategy - rendering it 'flexible' - and prevent or mitigate unwanted effects. Adaptation of the disposal strategy is related to the number and size of the disposal locations, volume of disposed sediment, disposal methods and time of disposal.

Firstly, the multichannel layout of the estuary is to be maintained. This is deemed important to support the main Long Term Vision functions safety, accessibility and naturalness. The loss of the multichannel system would lead to the disappearance of the intertidal flats and mudflats and thus lead to the loss of ecosystems. The main parameter and annex criterium used to evaluate this, is the volume of water in the secondary channel. The Western Scheldt is subdivided in 6 macrocells (morphological entities). For each of these, the water volume in the secondary channel should not drop below a certain level, as this would indicate undesired sedimentation which could ultimately lead to closing of the secondary channel.

Secondly, maximum ecological gain from disposal on the edges of the intertidal flats should be attained. This disposal location is one of three possible disposal sites. Disposal also takes place in the main and secondary channel of the estuary. In between these channels, intertidal flats with a high ecological value, exist. The ecological value is determined by the area of low-dynamical undeep water and intertidal areas (for settling, feeding, ...). The criterium here is that the surface of these areas, over the whole of the four disposal areas on the edges of the intertidal flats, should increase by 144 ha within five years after the start of the dredging and disposal. This means that the edges should neither become steeper (as this reduces the surface area), neither exaggeratively higher (leading to permanent dry-fall of the flats) or deeper. Within the second quality parameter, an ancillary criterium is that the stability of the disposed sediment (the net volume within the disposal area) should not decrease beyond a given limit. This parameter is used because it responds faster to sediment/erosion than the surface of ecologically valuable area because the latter needs time to develop through processes as the migration of dumped sediments towards the boundary of the intertidal flat.

Thirdly, the surface of environmentally valuable area in the Western Scheldt should be preserved. This parameter not only regards the edges of the intertidal flats but the entire Western Scheldt. Additionally, the height of the flat is monitored to prevent an undesirable buildup and dryfall of the flat, as well as the erosion of the salt marshes along the edge of the estuarium. 
Table 1: Summary of the criteria as shown in the Protocol Conditions for Flexible Disposal

\begin{tabular}{|l|l|l|l|}
\hline Parameter & $\begin{array}{l}\text { Multiple channel } \\
\text { system }\end{array}$ & $\begin{array}{l}\text { Edges of intertidal } \\
\text { flats }\end{array}$ & Ecology (in general) \\
\hline Desired situation & Preservation & $\begin{array}{l}\text { Additional ecological } \\
\text { valuable area at the } \\
\text { edges of the flats }\end{array}$ & $\begin{array}{l}\text { Preservation of the area of } \\
\text { ecological valuable area in } \\
\text { the Western Scheldt }\end{array}$ \\
\hline Concrete goals & $\begin{array}{l}\text { No undesired shallowing } \\
\text { of secondary channels }\end{array}$ & $\begin{array}{l}\text { Increase in surface of } \\
\text { low-dynamic area near } \\
\text { the edges of the flats }\end{array}$ & $\begin{array}{l}\text { No decrease in the surface } \\
\text { of ecological valuable area } \\
\text { or sediment composition }\end{array}$ \\
\hline $\begin{array}{l}\text { Monitoring } \\
\text { instrument }\end{array}$ & $\begin{array}{l}\text { Determination of the } \\
\text { water volume in the } \\
\text { secondary channel }\end{array}$ & $\begin{array}{l}\text { Ecotope charts } \\
\text { Volume of the four } \\
\text { specific disposal areas }\end{array}$ & $\begin{array}{l}\text { Ecotope charts } \\
\text { Height surveying } \\
\text { Sediment composition }\end{array}$ \\
\hline $\begin{array}{l}\text { Criterium } \\
\text { undesired effect }\end{array}$ & $\begin{array}{l}\text { Lower water volume } \\
\text { than present than initial } \\
\text { water volume minus the } \\
\text { disposal criterium in } \\
\text { each secondary channel }\end{array}$ & $\begin{array}{l}\text { Ecological valuable } \\
\text { area not created } \\
\text { Dumped sediments } \\
\text { are not stable enough }\end{array}$ & $\begin{array}{l}\text { Significant deterioration of } \\
\text { the long-term trend per } \\
\text { ecotope area, taking into } \\
\text { account the natural } \\
\text { variation }\end{array}$ \\
\hline
\end{tabular}

For the quality parameters summarized in Table 1, warning thresholds have been defined. On exceeding a threshold, the administration is taking adequate actions by either starting up additional investigation, either altering the disposal strategy. This latter is then aimed to mitigate the undesired consequence of the natural evolution (the background signal) combined with the response to the disposal in a given area (the anthropogenic impact).

\section{FROM MONITORING TO DECISION MAKING}

The evaluation of the quality parameters listed above requires intense monitoring, involving many partners which The Department of Maritime Access (Flemish authority) and Rijkswaterstaat Zeeland (Dutch authority) rely on. Relevant surveys for the Flexible Disposal monitoring and analysis include multi- and single beam bathymetric surveys, RTK topographic surveys, ADCP measurements (see Plancke et al., 2012), sediment and biological sampling and surveying, LIDAR... Additionally, all dredging and disposal activities are meticulously recorded.

Reports are produced to allow the follow-up of the flexible disposal strategy. Yearly, formal checking of the quality parameters and reporting of their status, is performed. Bi-yearly, a broader analysis is made of MONEOS-T monitoring parameters, expanded with biological parameters (eg., bird and seal counts) in a progress report.

Bi-monthly, an assembly of the authorities and their partners meet to discuss the latest monitoring results and insights in dredging and disposal activities. Monthly reports of dredging and dumping activities and morphological changes on edges of the intertidal flats are produced for this assembly. Long-term studies of the effects of dumping in the main channel, quarterly reports of morphological and biological monitoring on the flats, etc... further support the analysis of the effects of the dredging and dumping on the estuarine system. With all information, a plan is made to steer the disposal strategy for the next two months. This assembly is crucial in the flexible nature of the disposal strategy. The bi-monthly assembly assures that potential undesired effects are detected in a very early stage. Additional monitoring and analysis are key elements in the decision making process. 


\section{RESULTS}

In this section, results of the monitoring and the decision making procedure are illustrated.

Dredging and disposal volumes two years after start of the third deepening

The permit for the disposal of sediment between 2010 and 2015 includes maximum disposal volumes for the overall project, and per-year disposal limits. These quota are further subdivided in type of disposal area: intertidal flat edges, main and secondary channels and also subdivided in geographical parts within the Western Scheldt (the macrocells mentioned earlier). Table 2 shows that the largest part of the dredged sediment is to be dumped back into the main channel ( 24.5 million $\mathrm{m}^{3}$ ) whereas 22 million $\mathrm{m}^{3}$ of sediments are to be disposed in the secondary channels and nearly 20 million $\mathrm{m}^{3}$ on the edges of the intertidal flats.

The first year after the start of the deepening of the Western Scheldt, the main part of the volume ( 7.7 million $\mathrm{m}^{3}$ ) was related to the actual deepening, whereas in the second year, the volume is due to maintenance dredging. The EIA foresees in an intial maintenance dredging volume of 11.7 million $\mathrm{m}^{3}$ in the first years, to decrease after some years. In year two, the actual disposed volume is significantly lower than the expected volume.

On a yearly (or more frequent) basis, decisions are made to dispose in certain areas more or less than previously. The decisions are driven by the capacity of the disposal location, in combination with other factors described in the quality parameters.

Table 2: Maximum permitted disposal capacity (in $\mathrm{m}^{3}$ ) for the first five years of the deepening project and the volumes disposed during the first two years after the start of the deepening.

\begin{tabular}{|l|l|l|l|l|}
\hline & Main Channel & $\begin{array}{l}\text { Secondary } \\
\text { Channel }\end{array}$ & $\begin{array}{l}\text { Edges of } \\
\text { intertidal flats }\end{array}$ & Total \\
\hline Maximum & 24500000 & 22000000 & 19700000 & 66200000 \\
\hline Year 1 & 113010 & 2688363 & 9877960 & 12679332 \\
\hline Year 2 & 5095563 & 2489796 & 2503472 & 10088830 \\
\hline
\end{tabular}

\section{Autonomous sedimentation on the edge of the Rug van Baarland intertidal flat}

The 'Rug van Baarland' is an intertidal flat where an increase in valuable ecological area was to be created by disposal on the edge of the intertidal flat. During the first two years after the start of the deepening, it was observed that autonomous (natural) sedimentation was higher than the disposal volumes (Figure 1). So far, 1.3 million $\mathrm{m}^{3}$ of sediments were dumped in the disposal area, whereas the volume increase totalled 3.6 million $\mathrm{m}^{3}$.

A potential consequence of this was that not all disposal capacity could be used. Besides this, concerns existed over possible undesired sedimentation in the adjacent secondary channel 'Middelgat'. Although the shallowing of the edge of the flat, which would lead to an increase of the valuable ecological area, these concerns required an action or decision to be made. In order to mitigate the undesired sedimentation, and monitor the evolution of the autonomous sedimentation, it was decided in the bi-monthly assembly, not to dump sediments on the Rug van Baarland edge during the third year of the project. 


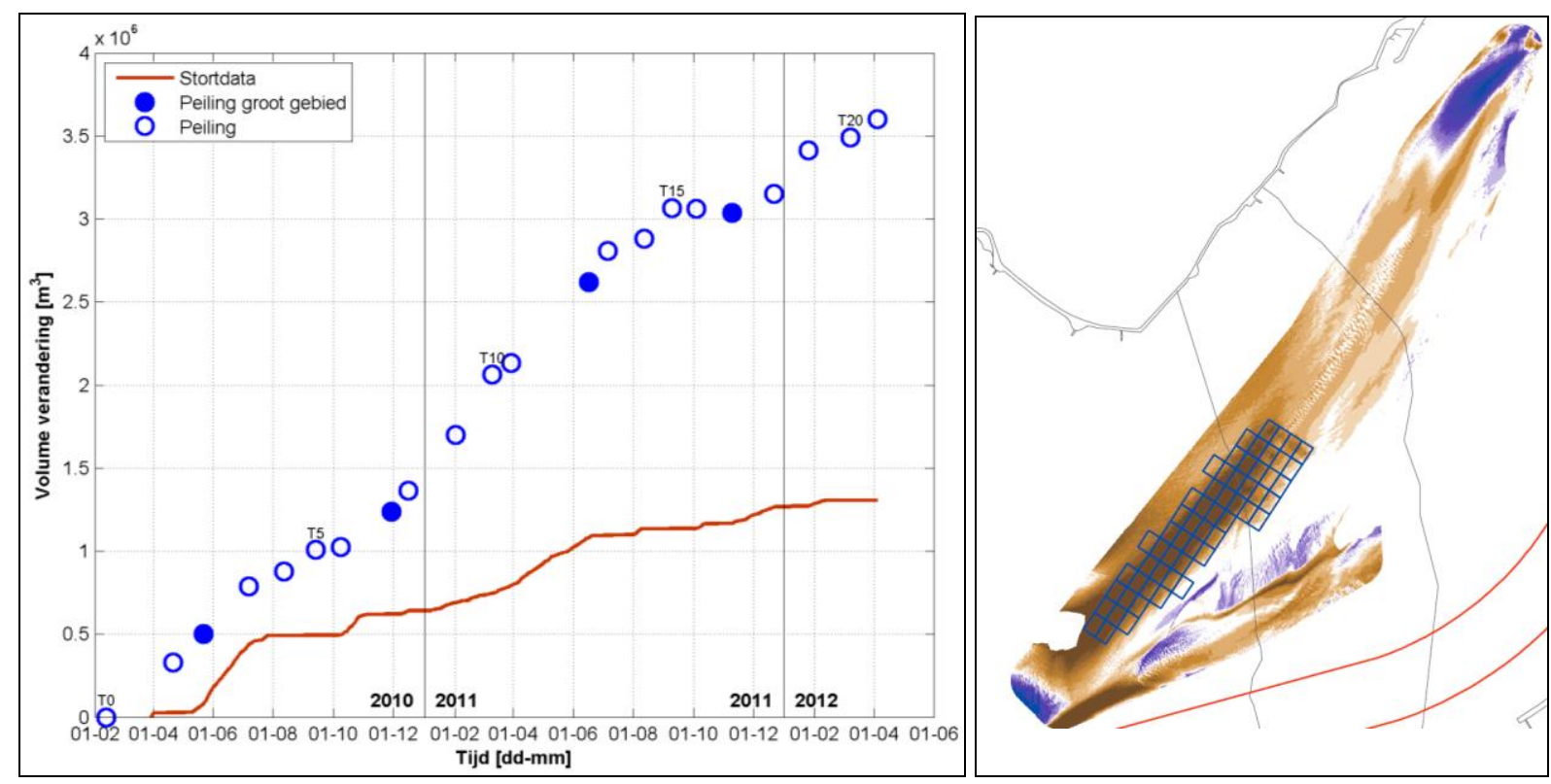

Figure 1: (left) Disposal volumes (red curve) on the Rug van Baarland intertidal flat edge, compared to the monitored volume increase (blue circles). Autonomous sedimentation leads to an undesired increase of the total sedimentation volume. Right: Difference map of the Rug van Baarland interitdal flat edge with sedimentation (brown) and erosion (blue) areas. The disposal area is indicated by the blue rectangles. The sedimentation is more widespread than the disposal area. Source: IMDC, 2012a.

\section{Disposal in the deep parts of the main channel}

Within the maintenance permit, disposal areas in the deep parts of the main channel are foreseen. The behaviour of the dumped sediments in these parts was analyzed for a period between October 2010 and October 2011 (IMDC, 2012b). Special attention was given to the stability of the dumped sediments and the (re)sedimentation at shallower locations in the main channel. This latter subject is of great concern because rapid resedimentation requires a high maintenance dreding intensity to guarantee a safe shipping activity. Three locations in the Western Scheldt and one location in the Lower Sea Scheldt were analyzed. For the study, dredging and disposal statistics where used together with volume calculations and morphological descriptions of detailed multibeam bathymetry. This analysis yielding general conclusions and recommendations for future disposal in the main channel.

The dumped dredging material erode from the deep parts of the main channel. Currently, it is expected that erosion half-lifes are about one half to one year. Increased sedimentation at the shallower parts could not be proved at this time but will be evident from possible changes in maintenance dredging intensity.

It was observed that the disposed sediment was most stable when it was dumped in a concentrated location as opposed to spread out over a larger area, and by dumping continuously in time. Near Walsoorden (Figure 2) a $600.000 \mathrm{~m}^{3}$ sediment body was built in multiple phases. On average, over a time span of 9.5 months, about $50 \%$ of the dumped sediment had eroded.

The stability appeared to be highest in the deepest part of the channel, except for locations where the depression was caused by a local turbulent feature caused by river infrastructure (Figure 3). Near the 'Nol van Ossenisse' groyne, 1.1 milion $\mathrm{m}^{3}$ was dumped. In the deepest part, $300.000 \mathrm{~m}^{3}$ of sediments were dumped in 5 months time; at the end of that period, only $24 \%$ of that volume was still present. In the immediate vicinity of the deeper parts, $940.000 \mathrm{~m}^{3}$ of sediments were dumped (within the same 5 months). Here, only $50 \%$ of the volume had eroded. In the greater surroundings, dumping also took place ( $70.000 \mathrm{~m}^{3}$ in total). There, not erosion, but additional sedimentation had occurred. 

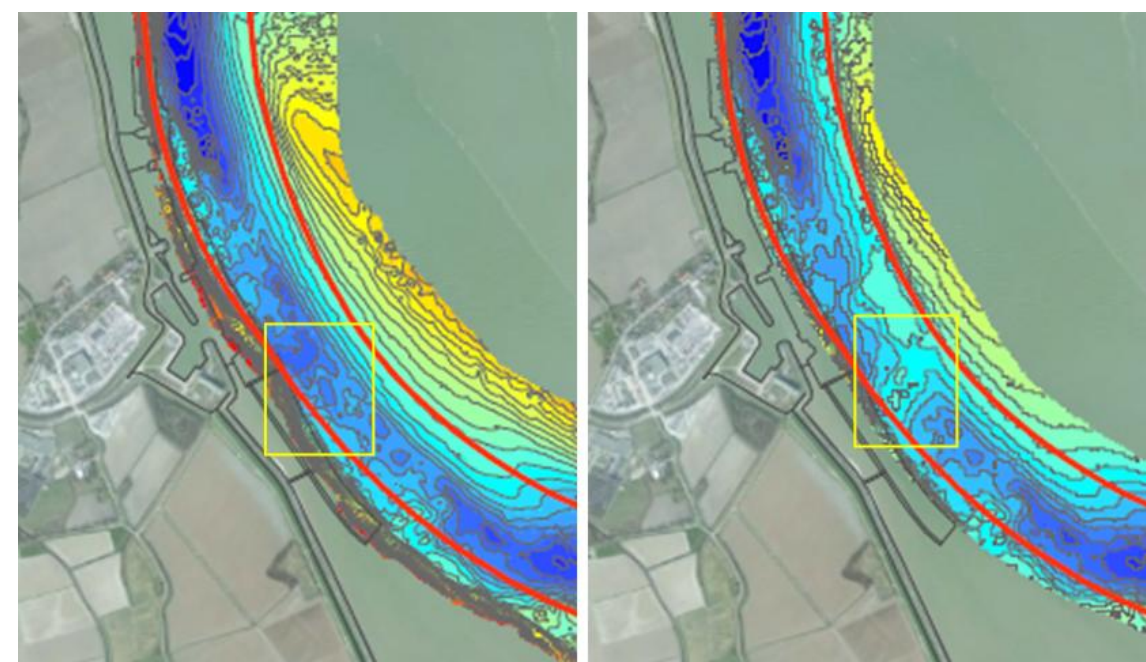

Figure 2: Creation of a concentrated sediment body in the main channel near Walsoorden. A concentrated body (nearly $600.000 \mathrm{~m}^{3}$ ) appeared more stable over time than spread-out disposal. Source: IMDC, 2012b.

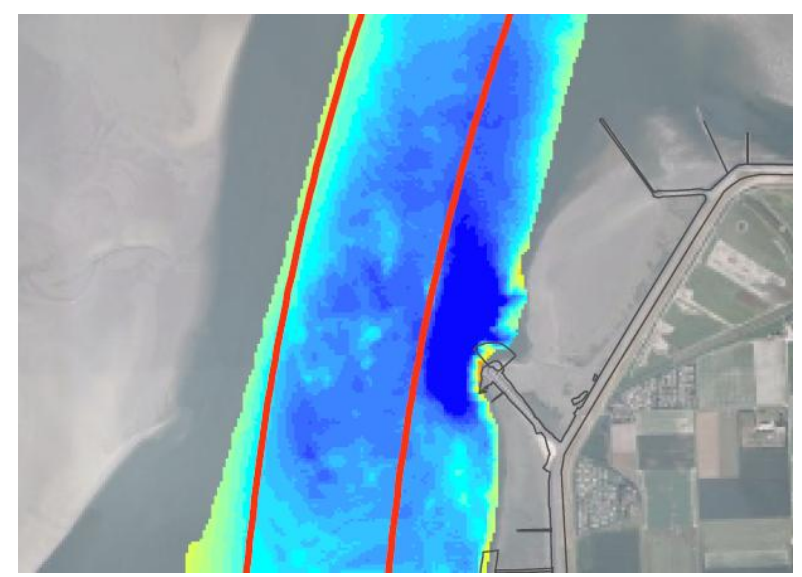

Figure 3: Disposal in the deepest part near the groyne 'Nol van Ossenisse' is unsuccessful due to the elevated turbulent energy of the deflected currents. Source: IMDC, 2012b.

In order to further refine the knowledge of erosion from the deep parts and resedimentation at the shallower parts, the study of the data continues on data produced until the end of 2012.

\section{CONCLUSION}

The Flexible Disposal Strategy is an approach to sediment disposal in the framework of the third deepening of the Scheldt that sets strict goals for positive morphological and ecological effects of the disposal activities. To achieve these goals and obey predefined quality parameters, intense monitoring of hydrodynamic, morphological and ecological parameters is carried out to support a decision making procedure. Through careful analysis, reporting and discussion, an assembly is able to steer or adapt the disposal strategy both on long- and short-term basis to prevent or mitigate undesired effects and promote the positive effects.

\section{REFERENCES}

Consortium Arcadis - Technum, Rijkswaterstaat Zeeland and afdeling Maritieme Toegang.

Milieueffectrapport Verruiming vaargeul Beneden-Zeeschelde en Westerschelde. Hoofdrapport. 2007. Accessed June 28, 2012. http://www.vnsc.eu/uploads/2011/01/milieueffectrapport.pdf 
IMDC. Monitoringprogramma flexibel storten. Maandelijkse rapportage april-mei 2012. 2012a. Unpublished reportn number I/RA/11353/11.015.

IMDC. Monitoringprogramma flexibel storten. Analyse van stortingen in de diepe delen van de hoofdgeul. 2012b. Unpublished report number I/RA/11353/11.076.

Plancke, Y., Vertommen, D., Beirinckx, K. \& Vos, G. High resolution topo-bathymetric and flow measurements and 2D-hydrodynamical modelling to evaluate the effects of the deepening of the navigation channel in the Western Scheldt. Hydro2012 - Taking care of the sea, Rotterdam, The Netherlands.

Schrijver, M. \& Plancke, Y. Uitvoeringsplan MONEOS-T 2008-2018. 2008. Middelburg: Rijkswaterstaat Zeeland; Antwerpen: Vlaamse Overheid. Accessed June 28, 2012. ww.vliz.be/imisdocs/ publications/140364.pdf

\section{BIOGRAPHIES}

Dr. Davy DEPREITER has a background in marine geology, geophysics and geobiology of seabed fluid flow and a broad knowledge in marine and near-surface terrestrial monitoring. This experience is now applied in the framework of studies regarding dredging activities and hydro- and morphodynamics of marine and estuarine systems. He is also responsible for the management of operational forecasting systems for hydrodynamic and hydrologic prediction and storm surge warnings.

Ir. Marc SAS is an expert in coastal and estuarine systems with over 30 years of experience in research and project management in the field of hydrodynamics, hydrology, sediment transport, mathematical modelling and survey campaigns in general, and related to the Scheldt Estuary specifically. He was responsible for the modelling teams working in the framework of the EIA Deepening Western Scheldt. He was involved in projects related to MONEOS-T, Moneos Safety \& Naturalness, Flexible Disposal, etc.

Kirsten BEIRINCKX is one of the environmental project-coordinators of the Flemish Government, Department of Maritime Access. In particular, she is responsible for the environmental aspects of the dredging and relocation works in the estuary of the river Scheldt. Furthermore, she manages the assembly of the authorities and their partners that discuss the latest monitoring results and insights in dredging and disposal activities, together with het Dutch counterpart Gert-Jan LIEK.

Gert-Jan LIEK M.Sc. has a background in coastal engineering and has been working for Rijkswaterstaat as an advisor on morphology since 2001. In that period he's been involved in a large number of studies on the morphological an hydrodynamical devolopment of the Western Scheldt. Together with his Flemish counterpart, Kirsten Beirickx, he is responsible for the execution of the flexibel disposal strategy and manages the assembly of the authorities that discuss the latest monitoring results and insights in dredging and disposal activities.

CONTACT DETAILS (of corresponding author only)

Davy Depreiter

International Marine \& Dredging Consultants (IMDC)

Coveliersstraat 15

B-2600 Berchem 


\section{BELGIUM}

Tel.: +32 32709295

Fax: +32 32356711

Email:davy.depreiter@imdc.be

Web site: www.imdc.be 